\title{
Profitabilitas, Leverage dan Pengungkapan Corporate Social Responsibility dengan Ukuran Perusahaan sebagai Variabel Pemoderasi
}

\section{Made Ayu Bintang Cyntia Dewi \\ Fakultas Ekonomi dan Bisnis \\ Universitas Udayana, Indonesia}

\author{
I Gusti Ayu Nyoman Budiasih \\ Fakultas Ekonomi dan Bisnis \\ Universitas Udayana, Indonesia
}

Surel: bintangcyntia@gmail.com

\section{ABSTRAK}

Penelitian bertujuan untuk mendapatkan bukti empiris pengaruh profitabilitas, leverage terhadap pengungkapan CSR dengan ukuran perusahaan sebagai pemoderasi. Penelitian ini berfokus pada perusahaan pertambangan, dimana perusahaan pertambangan memiliki dampak yang paling besar atas kerusakan lingkungan sekitar wilayah lingkungan perusahaan. Sampel yang didapat sebanyak 33 perusahaan menggunakan teknik purposive sampling. Teknik analisis data yangdigunakan moderated regression analysis (MRA). Hasil penelitian menunjukkan profitabilitas berpengaruh positif pada pengungkapan CSR, leverage berpengaruh positif pada pengungka pan CSR, ukuran perusahaan memperkuat pengaruh profitabilitas pada pengungkapan CSR dan ukuran perusahaan tidak mampu memperkuat pengaruh leverage pada pengungkapan CSR.

Kata Kunci: Pengungkapan CSR; Profitabilitas; Leverage; Ukuran Perusahaan.

\section{Profitability, Leverage and Corporate Social Responsibility Disclosure with Company Size as Moderating Variable}

\begin{abstract}
This study aims to obtainempirical evidence of the effect of profitability, leverage on CSR disclosure with firm size as moderating. This study focuses on mining companies, where mining companies have the greatest impact on environmental damage around the company's environmental area. The sample obtained was 33 companies using purposive sampling technique. The data analysis technique used was moderated regression analysis (MRA). The results show that profitability has a positive effect on CSR disclosure, leverage has a positive effect on CSR disclosure, firm size strengthens the effect of profitability on CSR disclosure and firm size is not able to streng then the influence of leverage on CSR disclosure.
\end{abstract}

Keywords: $\quad$ CSR Disclosure; Profitability; Leverage; Company Size.

Artikel dapat diakses: https:/ / ojs.unud.ac.id/index.php/Akuntansi/index

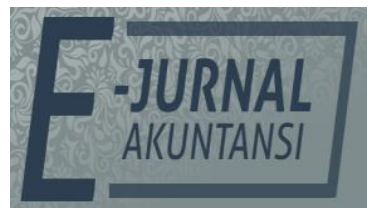

e-ISSN 2302-8556

Vol. 31 No. 11

Denpasar, November 2021 Hal. 2812-2826

DOI

10.24843/EJA.2021.v31.i11.p11

PENGUTIPAN:

Dewi, M. A. B. C., \& Budiasih, I. G. A. N. (2021).

Profitabilitas, Leverage dan

Pengungkapan Corporate Social Responsibility dengan

Ukuran Perusahaan sebagai Variabel Pemoderasi. E-Jurnal Akuntansi, 31(11), 2812-2826

RIWAYAT ARTIKEL:

Artikel Masuk: 5 April 2021 Artikel Diterima: 4 November 2021 


\section{PENDAHULUAN}

Keberhasilan suatu perusahaan bukan hanya dipengaruhi oleh faktor internal melainkan juga dipengaruhi oleh faktor eksternal antara lain masyarakat dan lingkungan atau komunitas disekitar perusahaan. Perusahaan sektor industri pertambangan merupakan perusahaan yang banyak menyumbangkan pendapatan pada negara. Terbukti banyak sekali perusahaan pertambangan yang terdaftar di Bursa Efek Indonesia (IDX Fact Book, 2017), tetapi dengan banyaknya perusahaan pertambangan menjadi hal yang mungkin akan merusak lingkungan alam sekitarnya. Perusahaan pertambangan lekat dengan pembukaan lahan yang dapat merugikan daerah aktivitas tersebut baik dalam segi lingkungan maupun sosial-ekonomi masyarakat. Tanggung jawab sosial perusahaan atau yang biasa disebut Corporate Social Responsibility (CSR) saat ini berkembang sangat baik ditingkat regional maupun internasional dan telah menjadi bagian yang sangat penting dalam bisnis. Semua perusahaan yang ingin tetap berkelanjutan serta memiliki keunggulan kompetitif harus menjadikan CSR sebagai bagian dari strategi bisnisnya (Dewi \& Suaryana, 2015). Perusahaan sebagai pelaku bisnis atau korporasi merupakan suatu badan yang mempunyai kegiatan tertentu untuk mencapai tujuan. Biasanya selain mencari laba, tujuan perusahaan mencakup pertumbuhan yang terus-menerus (growth), kelangsungan hidup (survival) dan kesan positif di mata publik (image). (Rengganis \& Dwija Putri, 2018) menyatakan perusahaan dalam upaya mempertahankan kelangsungan hidupnya selain untuk memperoleh laba juga memiliki tanggungjawab sosial.

Berkembangnya perusahan-perusahaan dapat menyebabkan terjadinya kerusakan lingkungan sekitar serta kesenjangan sosial. Timbulnya kesadaran untuk mengurangi dampak negatif yang disebabkan oleh perusahaan. Kesadaran untuk mengurangi dampak negatif tersebut adalah Corporate Social Responsibility (CSR). Komitmen dunia bisnis ataupun perusahaan dalam upaya kontribusi untuk perkembangan ekonomi yang berkelanjutan dengan cara memperhatikan tanggung jawab sosial perusahaan serta fokus pada keseimbangan antara kepedulian pada aspek sosial, ekonomis, dan lingkungan adalah pengertian dari CSR. Citra baik perusahaan di masyarakat akan lebih diminati oleh investor, oleh karena itu semakin baik citra perusahaan, maka akan meningkatkan loyalitas konsumen, sehingga profitabilitas perusahaan meningkat dan penjualan perusahaan akan membaik dalam jangka panjang. Manajemen dalam menjalankan bisnis perusahaan, seringkali tidak sesuai dengan keinginan pemilik perusahaan sehingga menjadikan laba tidak berkualitas yang seharusnya dapat digunakan oleh pengguna laporan keuangan untuk membuat keputusan yang terbaik.

Konsep pertanggungjawaban sosial di Indonesia belum mencapai keseragaman yang disesuaikan dengan kondisi di Indonesia bahkan kegiatan yang telah dilaksanakan selama ini belum diketahui secara luas oleh masyarakat Indonesia. Salah satu lambannya pelaksanaan pertanggungjawaban sosial di Indonesia adalah tidak adanya instrumen hukum yang komprehensif yang mengatur pertanggungjawaban sosial perusahaan. Pada saat ini, memang sudah terdapat peraturan yang terkait dengan pertanggungjawaban sosial perusahaan seperti Undang-Undang Republik Indonesia No. 32 Tahun 2009 tentang Pengelolaan dan Perlindungan Lingkungan Hidup yang isinya adalah upaya 
sistematis dan terpadu yang dilakukan untuk melestarikan fungsi lingkungan hidup dan mencegah terjadinya pencemaran dan/atau kerusakan lingkungan hidup yang meliputi perencanaan, pemanfaatan, pengendalian, pemeliharaan, pengawasan, dan penegakan hukum. Namun Undang-undang tersebut belum mampu mendorong pelaksanaan pertanggungjawaban sosial perusahaan di lapangan. Undang-undang tersebut hal yang diatur masih terbatas. Padahal pertanggungjawaban sosial perusahaan tidak saja berkaitan dengan tanggung jawab perusahaan terhadap lingkungan dalam arti sempit, namun juga dalam arti luas seperti tanggung jawab perusahaan terhadap pendidikan, perekonomian, dan kesejahteraan rakyat sekitar. Selain itu, masih kurangnya kesadaran perusahaan untuk mengungkapkan aktivitas perusahaannya secara luas dan masih banyak perusahaan di Indonesia yang mengabaikan keselarasan sosialnya. Ikatan Akuntan Indonesia (IAI) dalam pernyataan Standard Akuntansi Keuangan (PSAK) No.1 tahun 2009 paragraf 9 yang secara implisit menyarankan tanggung jawab akan masalah sosial sebagai berikut.

Perusahaan dapat pula menyajikan laporan tambahan seperti laporan mengenai lingkungan hidup dan laporan nilai tambah (value added statement), khususnya bagi industri dimana faktor-faktor lingkungan hidup memegang peranan penting dan bagi ind ustri yang menganggap pegawai sebagai kelompok pengguna laporan yang memegang peranan penting. Dari pernyataan PSAK, menunjukkan kepedulian akuntansi terhadap masalah-masalah sosial yang merupakan pertanggungjawaban sosial perusahaan. Belum adanya standar baku yang merinci peraturan mengenai pengungkapan sosial mengakibatkan perusahaan memiliki keleluasan dan kebebasan untuk mengungkapkan informasi sosial tersebut. Namun dengan adanya PSAK No.1 diharapkan adanya kesadaran perusahaan untuk melaporkan kegiatan sosialnya terhadap lingkungan sekitar perusahaan.

Debat corporate social responsibility di Indonesia semakin menguat terutama setelah dinyatakan dengan tegas dalam Undang-Undang Perseroan Terbatas (PT) No. 40 tahun 2007 pasal 74 ayat 1 tentang Corporate social responsibility dan Lingkungan yang isinya bahwa Perseroan Terbatas (PT) yang menjalankan usaha di bidang dan/ atau bersangkutan dengan sumber daya alam wajib menjalankan corporate social responsibility dan lingkungan. Peraturan lain yang menyentuh corporate social responsibility adalah UU No.25 tahun 2007 tentang Penanaman Modal. Pasal 15 (b) menyatakan bahwa "setiap penanam modal berkewajiban melaksanakan corporate social responsibility perusahaan". Peraturan tersebut disusun agar suatu perusahaan sadar dan bertanggungjawab atas seluruh aktivitas perusahaannya mulai dari produk, tenaga kerja dan limbah yang dihasilkan oleh perusahaan terutama perusahaan industri. Walaupun perusahaan tersebut tidak secara langsung melakukan eksploitasi sumber daya alam, tetapi selama kegiatan perusahaan tersebut berdampak pada fungsi kemampuan sumber daya alam maka perusahaan itu harus melaksanakan corporate social responsibility.

Teori Stakeholder mengatakan bahwa perusahaan bukanlah entitas yang hanya beroperasi untuk kepentingan sendiri namun harus memberikan manfaat bagi Stakeholdernya seperti pemegang saham, kreditur, konsumen, pemasok, pemerintah, masyarakat dan pihak lain (Ghozali \& Chariri, 2014). Teori 
Stakeholder memberikan syarat bahwa perusahaan harus memberi perhatian kepada Stakeholder karena Stakeholder dapat memberikan pengaruh dan dipengaruhi oleh perusahaan berkaitan dengan aktivitas dan kebijakan yang dilaksanakan (Dwipayadnya et al., 2015). Pengungkapan CSR penting karena para Stakeholder perlu mengetahui dan mengevaluasi sejauh mana perusahaan melaksanakan peranannya sesuai dengan keinginan Stakeholder, sehingga menuntut adanya akuntabilitas perusahaan atas kegiatan CSR yang telah dilakukannya (Riswari \& Cahyonowati, 2012). Pengungkapan sosial dianggap sebagai bagian dari dialog antara perusahaan dengan para Stakeholder.

Masih banyak kasus-kasus di Indonesia yang terjadi akibat kurangnya kesadaran perusahaan mengenai kegiatan pertanggung jawaban sosial, sehingga terjadi masalah terkait kerusakan lingkungan maupun konflik yang berhubungan kesejahteraan karyawan. Gambaran fenomena kegagalan CSR terjadi beberapa kali dan beberapa perusahaan besar yang terlibat dalam hal itu, seperti PT. Adaro Tbk., PT. Arutmin, dan PT. Kideco Jaya Agung, serta PT. Freepot. Kasus yang cukup besar adalah kasur yang melibatkan PT Newmont Nusa Tenggara, yang diduga melakukan pembuangan tailing ke laut lepas. Fenomena kerusakan lingkungan juga terjadi pada kasus PT Semen Indonesia dimana pada lima bulan terakhir warga Rembang mengeluhkan kondisi jalan rusak, tanaman pada sawah warga tercemari debu dan mempengaruhi hasil panen yang berujung pada penolakan pengoperasian perusahaan tersebut. Hal-hal tersebut yang menimbulkan perhatian pada penerapan pengungkapan CSR, karena pencemaran lingkungan yang terjadi dapat dikategorikan ekspolitasi SDA (Sumber Daya Alam), keamanan lingkungan dan produk berkualitas, peningkatan atas limbah dan polusi, investasi yang disalahgunakan, dan hal lainnya.

Namun, ada juga industri pertambangan yang menjalankan kegiatannya dengan memperhatikan dan menjaga kelestarian lingkungan hidup sekitarnya. PT Kaltim Prima Coal menunjukkan citranya sebagai perusahaan yang peduli terhadap komunitas sekitarnya melalui kesuksesannya dalam menjalankan program baik di bidang lingkungan, ekonomi, maupun sosial sehingga menerima penghargaan sebagai The Most Outstanding Recognition Awards dalam CSR Awards 2005 yang diselenggarakan oleh Surindo bekerjasama dengan Corporate Forum For Community Development (CFD) oleh majalah SWA dan Mark Plus.

Hal-hal yang mempengaruhi CSR salah satunya yaitu Profitabilitas. Profitabilitas menunjukkan kemampuan perusahaan dalam menghasilkan laba selama periode tertentu. Semakin tinggi nilai profitabilitas maka semakin besar kemampuan perusahaan dalam menghasilkan laba. Kondisi keuangan perusahaan yang dapat dilihat melalui laporan keuangan perusahaan. Perusahaan dengan tingkat profitabilitas yang baik akan dipandang lebih baik dimata para investor. Tingkat profitabilitas yang positif menunjukkan bahwa perusahaan menghasilkan laba, sebaliknya dengan tingkat profitabilitas yang negatif berarti menunjukkan bahwa perusahaan mengalami kerugian. Pada analisis laporan keuangan, rasio ini paling sering digunakan, karena mampu menunjukan keberhasilan perusahaan menghasilkan keuntungan. ROA digunakan sebagai proksi dari profitabilitas karena ROA dapat menunjukkan efisiensi pengelolaan seluruh aset yang dimiliki oleh perusahaan, baik aset lancar maupun aset tidak lancar. Penelitian yang dilakukan (Purba \& Yadnya, 2015), (Yanti \& Budiasih, 
2016), (Bhuyan \& Perera, 2017) dan (Platonova et al., 2018) menyatakan Profitabilitas berpengaruh positif terhadap pengungkapan tanggung jawab sosial perusahaan. Namun, (Rofiqkoh \& Priyadi, 2016); (Wulandari \& Sudana, 2018); (McWilliams \& Siegel, 2001) serta (Gunawan et al., 2009) menyatakan bahwa profitabilitas tidak mempengaruhi pengungkapan tanggung jawab sosial perusahaan.

Selain profitabilitas, hal yang mempengaruhi CSR selanjutnya adalah Leverage. Leverage adalah kemampuan perusahaan untuk menutup kewajiban finansial jangka pendek dan juga jangka panjang, atau menaksir seberapa jauh perusahan dibiayai oleh hutang (Wiagustini, 2014:85). Debt Equity Ratio (DER) merupakan rasio hutang (debt) terhadap modal (equity) yaitu rasio yang paling sering dipakai untuk menganalisa kesehatan perusahaan. Rasio tersebut digunakan untuk memberikan gambaran mengenai struktur modal yang dimiliki perusahaan, sehingga dapat dilihat tingkat resiko tak tertagihnya suatu utang. Semakin tinggi tingkat leverage semakin besar kemungkinan akan melanggar perjanjian kredit sehingga perusahaan akan berusaha untuk melaporkan laba sekarang lebih tinggi. Menurut (Trisna Dewi \& Ratna Sari, 2019), perusahaan dengan rasio leverage yang tinggi memiliki kewajiban untuk melakukan ungkapan yang lebih luas dari pada perusahaan dengan rasio leverage yang rendah. Hasil penelitian yang dilakukan oleh (Purba \& Yadnya, 2015), (Yanti \& Budiasih, 2016), (Rofiqkoh \& Priyadi, 2016) serta (Felicia \& Rasmini, 2015) menemukan bahwa variabel leverage berpengaruh positif terhadap pengungkapan tanggung jawab sosial perusahaan. Sedangkan (Pradnyani \& Sisdyani, 2015) dan (Wulandari \& Sudana, 2018) menemukan bahwa leverage tidak mempengaruhi pengungkapan tanggung jawab sosial perusahaan.

Adanya hasil yang tidak konsisten menyebabkan dapat digunakannya teori kontingensi untuk merekonsiliasi perbedaan dari penelitian ini. Kontingensi memungkinkan adanya pendekatan variabel-variabel yang dapat bertindak sebagai pemoderasi yang mempengaruhi hubungan antara profitabilitas dan leverage pada pengungkapan CSR. Penelitian ini menggunakan ukuran perusahaan sebagai pemoderasi sebagai faktor kontingensi. Tujuan penambahan variabel moderasi dengan menggunakan ukuran perusahaan yang dilihat dari total aset perusahaan adalah untuk mengetahui peran ukuran perusahaan memoderasi pengaruh profitabilitas dan leverage terhadap pengungkapan CSR. Ukuran perusahaan merupakan suatu skala yang berfungsi untuk mengklasifikasikan besar kecilnya entitas bisnis. Skala perusahaan dapat mempengaruhi luas pengungkapan informasi dalam laporan keuangan mereka. Menurut (Cowen et al., 1987) perusahan yang lebih besar dengan aktivitas dan pengaruh yang lebih besar terhadap masyarakat akan memiliki pemegang saham yang mungkin memperhatikan program sosial yang dibuat perusahaan dan laporan tahunan akan digunakan untuk menyebarkan informasi tentang CSR yang dilakukan oleh perusahaan.

Berdasarkan uraian tersebut, profitabilitas dan leverage dipilih kembali dalam penelitian ini dengan menambahkan ukuran perusahaan sebagai variabel moderasi dikarenakan ingin diteliti kembali variabel tersebut yang dilihat dari penelitian sebelumnya yang masih berbeda-beda dan belum konsisten. Dengan perbedaan yang dilakukan pada penelitian ini diharapkan dapat memberikan 
hasil yang lebih signifikan dari penelitian sebelumnya dan topik yang diajukan menjadi menarik untuk diteliti kembali. Sektor pertambangan dipilih sebagai lokasi penelitian karena sektor pertambangan memiliki dampak yang paling besar atas kerusakan lingkungan sekitar wilayah lingkungan perusahaan.

Grand theory yang digunakan di penelitian ini adalah teori Stakeholder. Stakeholder adalah semua pihak internal dan eksternal, yang dapat mempengaruhi atau dipengaruhi oleh perusahaan, baik secara langsung maupun tidak langsung (Hadi, 2011:93). Teori Stakeholder menyatakan bahwa perusahaan bukanlah entitas yang hanya beroperasi untuk kepentingan sendiri, namun harus memberikan manfaat kepada seluruh Stakeholder-nya (pemegang saham, kreditur, konsumen, supplier, pemerintah, masyarakat, analisis dan pihak lainnya), keberadaan perusahaan sangat dipengaruhi oleh dukungan yang diberikan oleh Stakeholder kepada perusahaan (Ghozali \& Chariri, 2014).

Teori Stakeholder digunakan untuk menjelaskan hubungan antara masyarakat dan perusahaan. Hal itu perlu karena perusahaan harus mempertimbangkan kepentingan semua pihak atau masyarakat yang terkena dampak aksi korporasi dalam pengambilan keputusan. Menurut teori Stakeholder, meningkatnya tanggung jawab sosial perusahaan membuat perusahaan lebih menarik bagi masyarakat dan investor (Wiyarna \& Sudana, 2019). Teori Stakeholder memberikan fondasi bahwa sebuah perusahaan harus mampu memberikan manfaat bagi pemangku kepentingan. Manfaat ini dapat disediakan dengan menerapkan program CSR. Adanya program CSR di perusahaan diharapkan untuk meningkatkan kesejahteraan bagi karyawan, pelanggan, dan masyarakat setempat. Dengan demikian diharapkan dapat membangun hubungan yang baik antara perusahaan dan lingkungannya.

Strategi untuk menjaga hubungan dengan para Stakeholder perusahaan adalah dengan melaksanakan CSR, dengan pelaksanaan CSR diharapkan keinginan dari Stakeholder dapat terakomodasi sehingga akan menghasilkan hubungan yang harmonis antara perusahaan dengan Stakeholdernya. Hubungan yang harmonis akan berakibat pada perusahaan dapat mencapai keberlanjutan atau kelestarian perusahaannya (Andriana \& Anggara, 2019).

\section{METODE PENELITIAN}

Penelitian dapat memberikan informasi yang diperlukan untuk memandu manajer mengambil keputusan yang terinformasi agar bisa memecahkan masalah secara sukses. Informasi yang diperoleh bisa berasal dari analisis mendalam terhadap yang dikumpulkan dari tangan pertama, atau data yang telah tersedia. Penelitian dibagi menjadi dua macam yaitu penelitian kuantitatif dan penelitian kualitatif (Sekaran, 2006). Berdasarkan pendekatan analisisnya, penelitian ini dapat diklasifikasikan ke dalam penelitian kuantitatif, yang dalam penelitian ini adalah pengaruh profitabilitas dan leverage pada pengungkapan Corporate Social Responsibility dengan ukuran perusahaan sebagai pemoderasi dalam laporan keuangan tahunan perusahaan pertambangan di BEI. Data sekunder yang digunakan adalah daftar perusahaan pertambangan yang terdaftar di Bursa Efek Indonesia, yang didapat pada website resmi www.idx.co.id. bahwa jumlah perusahaan yang digunakan sebagai sampel penelitian adalah sebanyak 11 
perusahaan pertambangan dengan periode pengamatan adalah 3 tahun, sehingga jumlah sampel amatan yang digunakan dalam penelitian ini adalah sebanyak 33. Teknik analisis data dalam penelitian ini dilakukan dengan menggunakan Moderated Regression Analysis (MRA) dengan menggunakan program SPSS (Statistical Product and Service Solution). Model persamaan regresi dalam penelitian ini dinyatakan sebagai berikut.

$Y=\alpha+\beta_{1} X_{1}+\beta_{2} X_{2}+\beta_{3} Z+\beta_{4} X_{1} Z+\beta_{5} X_{2} Z+\varepsilon$

Keterangan:

$\mathrm{Y}=$ Variabel dependen pengungkapan CSR

$\mathrm{X}_{1}=$ Variabel independen profitabilitas

$\mathrm{X}_{2} \quad=$ Variabel independen leverage

$\mathrm{Z} \quad=$ Variabel Moderasi ukuran perusahaan

a $\quad=$ Konstanta

$\beta_{1}-\beta_{5}=$ Koefisien regresi (nilai peningkatan atau pun penurunan)

$\varepsilon \quad=$ Error Term, yaitu tingkat kesalahan penduga dalam penelitian.

\section{HASIL DAN PEMBAHASAN}

Hasil Uji Analisis Statistik Deskriptif

Analisis statistik deskriptif dipergunakan untuk menggambarkan atau menjelaskan suatu data pada variabel penelitian berdasarkanjumlah sampel, nilai rata - rata (mean), standar deviasi, nilai maksimum, dan nilai minimum. Hasil analisis statistik deskriptif dapat dilihat pada Tabel 1.

Tabel 1. Hasil Uji Analisis Statistik Deskriptif

\begin{tabular}{llllll}
\hline Variabel & $\mathrm{N}$ & Min. & Max. & Mean & Std. Deviasi \\
\hline ROA & 33 & $-20,78$ & 153,83 & 8,386 & 27,749 \\
DER & 33 & $-591,18$ & 350,75 & 70,918 & 143,668 \\
CSR & 33 & 0,05 & 0,84 & 0,311 & 0,172 \\
SIZE & 33 & 24,77 & 31,14 & 28,480 & 1,747 \\
ROA*SIZE & 33 & $-640,44$ & 3810,37 & 221,399 & 697,494 \\
DER*SIZE & 33 & $-14643,53$ & 9642,12 & 2076,114 & 3773,846 \\
\hline
\end{tabular}

Sumber: Data Penelitian, 2020

Berdasarkan Tabel 1, dapat diuraikan Return On Assets (X1) sebagai proksi dari profitabilitas memiliki nilai minimum sebesar -20,78 dan nilai maksimum sebesar 153,83 . Nilai rata-rata sebesar 8,386 yang berarti rata-rata ROA pada sampel amatan dalam penelitian ini bernilai 8,386. Standar deviasi sebesar 27,749 yang memiliki makna bahwa terjadi penyimpangan nilai ROA pada nilai rataratanya sebesar 27,749. Debt Equity Ratio (X2) sebagai proksi dari leverage memiliki nilai minimum yaitu sebesar -591,18 dan nilai maksimum sebesar 350,75. Nilai rata-rata sebesar 70,918 yang berarti rata-rata DER pada sampel amatan dalam penelitian ini bernilai 70,918. Standar deviasi sebesar 143,668 yang memiliki makna bahwa terjadi penyimpangan nilai pertumbuhan penjualan pada nilai rataratanya sebesar 143,668.

Pengungkapan Corporate Social Responsibility (Y) memiliki nilai minimum sebesar 0,05 dan nilai maksimum sebesar 0,84. Nilai rata-rata sebesar 0,311 yang berarti rata-rata CSR pada sampel amatan dalam penelitian ini bernilai 0,311. Standar deviasi sebesar 0,172 yang memiliki makna bahwa terjadi penyimpangan nilai CSR pada nilai rata-ratanya sebesar 0,172 . Size $(Z)$ sebagai proksi dari ukuran 
perusahaan memiliki nilai minimum sebesar 24,77 dan nilai maksimum sebesar 31,14 . Nilai rata-rata sebesar 28,480 yang berarti rata-rata Size pada sampel amatan dalam penelitian ini bernilai 28,4806. Standar deviasi sebesar 1,747 yang memiliki makna bahwa terjadi penyimpangan ukuran perusahaan pada nilai rata-ratanya sebesar 1,747 .

Interaksi ROA dan Size memiliki nilai minimum sebesar -640,44 dan nilai maksimum sebesar 3810,37. Nilai rata-rata sebesar 221,399 yang berarti rata-rata interaksi ROA dan Size pada sampel amatan dalam penelitian ini bernilai 221,399. Standar deviasi sebesar 697,494 yang memiliki makna bahwa terjadi penyimpangan interaksi ROA dan Size pada nilai rata-ratanya sebesar 697,494. Interaksi DER dan Size memiliki nilai minimum sebesar -14643,53 dan nilai maksimum sebesar 9642,12. Nilai rata-rata sebesar 2076,114 yang berarti rata-rata interaksi DER dan Size pada sampel amatan dalam penelitian ini bernilai 2076,114. Standar deviasi sebesar 3773,846 yang memiliki makna bahwa terjadi penyimpangan interaksi DER dan Size pada nilai rata-ratanya sebesar 3773,846.

Tabel 2. Hasil Uji Moderated Regression Analysis (MRA)

\begin{tabular}{lccccc}
\hline & Unstandardized Coefficients & \multicolumn{3}{c}{ Standardized Coefficients } & \\
\hline \multicolumn{1}{c}{ Variabel } & $B$ & Std. Error & Beta & $\mathrm{t}$ & Sig. \\
\hline (Constant) & $-0,849$ & 1,854 & & $-0,458$ & 0,651 \\
ROA & 0,007 & 0,003 & 1,040 & 2,972 & 0,006 \\
DER & 0,001 & 0,001 & 0,917 & 2,355 & 0,026 \\
SIZE & 0,314 & 0,551 & 0,097 & 0,569 & 0,574 \\
ROA*SIZE & $-0,003$ & 0,001 & $-0,584$ & $-2,948$ & 0,007 \\
DER*SIZE & 0,000 & 0,000 & 0,045 & 0,113 & 0,911 \\
\hline
\end{tabular}

Sumber: Data Penelitian, 2020

Berdasarkan hasil Uji Moderated Regression Analysis (MRA) yang disajikan pada Tabel 2, maka dapat dibuat persamaan regresi, yaitu.

$Y=\alpha+\beta 1 X 1+\beta 2 X 2+\beta 3 Z+\beta 4 X 1 Z+\beta 5 X 2 Z+\varepsilon$

$Y=-0,849+0,007 X 1+0,001 X 2+0,314 Z-0,003 X 1 Z+0,000 X 2 Z+\varepsilon$

Berdasarkan persamaan regresi, dapat dijelaskan Nilai konstanta ( $a$ ) sebesar $-0,849$ memiliki arti apabila semua variabel independen konstan, maka Pengungkapan CSR akan naik sebesar 84,9 persen. Nilai koefisien regresi ROA (X1) sebagai proksi dari profitabilitas yaitu 0,007 memiliki arti bahwa ROA memiliki hubungan positif terhadap Pengungkapan CSR, dimana apabila ROA (X1) meningkat sebesar 1 satuan, maka Pengungkapan CSR (Y) akan meningkat sebesar 0,7 persen dengan asumsi variabel bebas lainnya konstan. Nilai koefisien regresi DER (X2) sebagai proksi dari leverage yaitu 0,001 memiliki arti bahwa DER memiliki hubungan positif terhadap pengungkapan CSR, dimana apabila DER (X2) meningkat sebesar 1 satuan, maka pengungkapan CSR $(Y)$ akan meningkat sebesar 0,1 persen dengan asumsi variabel bebas lainnya konstan. Nilai koefisien regresi Size (X3) sebagai proksi dari ukuran perusahaan yaitu 0,314 memiliki arti bahwa Size memiliki hubungan positif terhadap pengungkapan CSR, dimana apabila Size (X3) meningkat sebesar 1 satuan, maka pengungkapan CSR (Y) akan meningkat sebesar 31,4 persen dengan asumsi variabel bebas lainnya konstan. Nilai koefisien regresi interaksi ROA dan Size sebesar -0,003 memiliki arti yaitu meningkatnya profitabilitas dengan ukuran perusahaan sebagai pemoderasi sebesar 1 satuan akan diikutioleh meningkatnya pengungkapan CSR $(\mathrm{Y})$ sebesar 0,3 persen dengan 
asumsi semua variabel bebas lainnya konstan. Nilai koefisien regresi interaksi DER dan Size sebesar 0,000 memiliki arti yaitu meningkatnya leverage dengan ukuran perusahaan sebagai pemoderasi sebesar 1 satuan akan diikuti oleh meningkatnya pengungkapan CSR $(Y)$ sebesar 0,002 persen dengan asumsi semua variabel bebas lainnya konstan.

Pengujian ini dilakukan untuk mengetahui pengaruh secara simultan variabel-variabel bebas terhadap variabel terikat. Apabila nilai signifikansi lebih kecil dari 0,05 maka secara simultan variabel bebas yang digunakan berpengaruh terhadap variabel terikat. Adapun hasil pengujian Uji F dapat dilihat pada Tabel 3.

Tabel 3. Hasil Uji F

\begin{tabular}{llccccc}
\hline & Model & Sum of Squares & df & Mean Square & F & Sig. \\
\hline 1 & Regression & 0,439 & 5 & 0,088 & 2,880 & 0,033 \\
& Residual & 0,824 & 27 & 0,031 & & \\
Total & 1,263 & 32 & & & \\
\hline
\end{tabular}

Sumber: Data Penelitian, 2020

Tabel 3, menunjukkan bahwa nilai signifikansi sebesar 0,033 lebih kecil dari 0,05. Jadi dapat disimpulkan bahwa model Moderated Regression Analysis (MRA) layak digunakan. Uji Koefisien Determinasi $\left(\mathrm{R}^{2}\right)$ seberapa jauh kemampuan variansi variabel independen dalam menerangkan variansi variabel dependen. Koefisien determinasi yang digunakan dalam penelitian ini adalah adjusted $R^{2}$, karena apabila suatu variabel ditambahkan ke dalam model regresi dan hasilnya tidak signifikan maka akan mengalami kenaikan yang tidak terlalu tinggi. Hasil Uji Koefisien Determinasi dalam penelitian ini dapat dilihat pada Tabel 4.

Tabel 4. Hasil Uji Koefisien Determinasi ( $\left.\mathbf{R}^{2}\right)$

\begin{tabular}{ccccc}
\hline Model & $\mathrm{R}$ & R Square & Adjusted R Square & Std. Errorof the Estimate \\
\hline 1 & 0,590 & 0,348 & 0,227 & 0,1746818 \\
\hline
\end{tabular}

Sumber: Data Penelitian, 2020

Berdasarkan Tabel 4, dapat dilihat bahwa nilai dari Adjusted $R$ Square adalah sebesar 0,227 atau 22,7 persen yang memiliki arti bahwa 22,7 persen variansi pengungkapan CSR dipengaruhi oleh variansi ROA, DER dan Size, sisanya sebesar 77,3 persen dipengaruhi oleh variabel-variabel lain yang tidak dijelaskan dalam penelitian ini. Pengujian hipotesis (Uji t) dilakukan untuk menunjukkan pengaruh semua variabel independen secara parsial pada variabel dependen. Pengaruh tersebut dapat dilihat dengan membandingkan niali signifikansi masing-masing variabel independen dengan level of significant yaitu sebesar 5 persen $(0,05)$. Apabila nilai signifikansi variabel independen lebih kecil dari 5 persen $(0,05)$ maka variabel independen secara parsial berpengaruh terhadap variabel dependen ( $\mathrm{H}_{0}$ ditolak dan $\mathrm{H}_{1}$ diterima). Hasil Uji Hipotesis (Uji t) dalam penelitian ini dapat dilihat pada Tabel 5 . 
Tabel 5. Hasil Uji Hipotesis (Uji t)

\begin{tabular}{lrrrrr}
\hline & \multicolumn{3}{c}{ Unstandardized Coefficients } & \multicolumn{3}{c}{ Standardized Coefficients } \\
Variabel & \multicolumn{1}{c}{ Std. Error } & Beta & \multicolumn{1}{c}{ t } & \multicolumn{1}{c}{ Sig. } \\
\hline (Constant) & $-0,849$ & 1,854 & & $-0,458$ & 0,651 \\
ROA & 0,007 & 0,003 & 1,040 & 2,972 & 0,006 \\
DER & 0,001 & 0,001 & 0,917 & 2,355 & 0,026 \\
SIZE & 0,314 & 0,551 & 0,097 & 0,569 & 0,574 \\
ROA*SIZE & $-0,003$ & 0,001 & $-0,584$ & $-2,948$ & 0,007 \\
DER*SIZE & 0,00002197 & 0,000 & 0,045 & 0,113 & 0,911 \\
\hline
\end{tabular}

Sumber: Data Penelitian, 2020

Berdasarkan Tabel 5, dapat dijabarkan hasil Uji Hipotesis (Uji t) dalam penelitian ini, yaitu Hasil Uji Hipotesis pertama $\left(\mathrm{H}_{1}\right)$. Tabel 5 menunjukkan bahwa Profitabilitas memiliki nilai signifikansi sebesar 0,006 dengan nilai koefisien bernilai positif sebesar 0,007. Nilai signifikansi sebesar 0,006 lebih kecil dari level of significant yaitu sebesar 5 persen $(0,05)$ yang mengindikasikan bahwa $\mathrm{H}_{0}$ ditolak dan $\mathrm{H}_{1}$ diterima, dengan kata lain Profitabilitas berpengaruh positif pada pengungkapan CSR.

Hasil Uji Hipotesis kedua $\left(\mathrm{H}_{2}\right)$. Tabel 5 menunjukkan bahwa Leverage memiliki nilai signifikansi sebesar 0,026 dengan nilai koefisien bernilai positif sebesar 0,001. Nilai signifikansi sebesar 0,026 lebih kecil dari level of significant yaitu sebesar 5 persen $(0,05)$ yang mengindikasikan bahwa $\mathrm{H}_{0}$ ditolak dan $\mathrm{H}_{2}$ diterima, dengan kata lain Leverage berpengaruh positif pada pengungkapan CSR.

Hasil Uji Hipotesis ketiga $\left(\mathrm{H}_{3}\right)$. Tabel 5 menunjukan bahwa Profitabilitas yang didukung oleh ukuran perusahaan sebagai pemoderasi memiliki nilai signifikansi sebesar 0,007 dengan nilai koefisien bernilai negatif sebesar -0,003 Nilai signifikansi sebesar 0,007 lebih kecil dari level of significant yaitu sebesar 5 persen $(0,05)$ yang mengindikasikan bahwa $\mathrm{H}_{0}$ ditolak dan $\mathrm{H}_{3}$ diterima, dengan kata lain Ukuran Perusahaan memperkuat pengaruh profitabilitas pada pengungkapan CSR.

Hasil Uji Hipotesis keempat $\left(\mathrm{H}_{4}\right)$. Tabel 5 menunjukan bahwa Leverage yang didukung oleh ukuran perusahaan sebagai pemoderasi memiliki nilai signifikansi sebesar 0,911 dengan nilai koefisien bernilai positif sebesar 0,00002197. Nilai signifikansi sebesar 0,911 lebih besar dari level of significant yaitu sebesar 5 persen $(0,05)$ yang mengindikasikan bahwa $\mathrm{H}_{0}$ diterima dan $\mathrm{H}_{4}$ ditolak, dengan kata lain Ukuran Perusahaan tidak memoderasi pengaruh leverage pada pengungkapan CSR.

Berdasarkan hasil penelitian menunjukkan bahwa profitabilitas berpengaruh positif terhadap pengungkapan CSR sehingga hipotesis pertama dalam penelitian ini diterima. Hasil penelitian memberikan makna bahwa semakin tinggi profitabilitas perusahaan, maka perusahaan memiliki dana yang digunakan untuk mengungkapkan informasi CSR. Dengan profitabilitas yang tinggi, manajemen perusahaan wajib untuk mengungkapkan informasi CSR sehingga menimbulkan pengaruh positif mengenai posisi perusahaan. Hasil penelitian ini sejalan dengan hasil penelitian yang dilakukan oleh (Purba \& Yadnya, 2015) dan (Pradnyani \& Sisdyani, 2015) yang menyatakan bahwa profitabilitas berpengaruh positif terhadap CSR. Hasil penelitian serupa juga 
dilakukan oleh (Yanti \& Budiasih, 2016) yang menyatakan bahwa profitabilitas berpengaruh positif terhadap pengungkapan CSR. Teori Stakeholder menyatakan bahwa perusahaan harus mempertimbangkan kepentingan semua pihak atau masyarakat yang terkena dampak aksi korporasi dalam pengambilan keputusan. Menurut teori Stakeholder ini, meningkatnya tanggung jawab sosial perusahaan membuat perusahaan lebih menarik bagi masyarakat dan investor (Wiyarna \& Sudana, 2019). Profitabilitas perusahaan yang diproksikan melalui Return On assets (ROA) menunjukkan perbandingan antara laba dengan total aset yang digunakan untuk menghasilkan laba tersebut. Semakin tinggi tingkat profitabilitas perusahaan maka akan semakin besar pula pengungkapan informasi sosialnya (Wardhani, 2013). Profitabilitas suatu perusahaan merupakan faktor yang membuat manajemen menjadi bebas dan fleksibel untuk mengungkapkan pertanggung jawaban sosial kepada pemegang saham, sehingga semakin tinggi tingkat profitabilitas perusahaan maka semakin besar pengungkapan informasi sosial. Hal ini sesuai dengan Teori Stakeholder yang menyatakan bahwa perusahaan memiliki tanggung jawab kepada para para pemegang saham untuk memenuhi kebutuhan informasi demi mempertahankan dukungan dari para pemegang saham. Semakin tinggi tingkat profitabilitas, semakin rinci pula informasi yang diberikan oleh manajer sebab pihak manajemen ingin meyakinkan investor tentang profitabilitas perusahaan, sehingga pengungkapan CSR yang dilakukan oleh perusahaan juga semakin besar.

Berdasarkan hasil penelitian menunjukkan bahwa leverage berpengaruh positif terhadap pengungkapan CSR sehingga hipotesis kedua dalam penelitian ini diterima. Hasil penelitian memberikan makna bahwa semakin tinggi tingkat leverage perusahaan, maka Semakin efektif penggunaan modal kerja dan semakin cepat modal kerja berputar semakin besar keuntungan yang didapatkan untuk meningkatkan pengungkapan CSR perusahaan. Hasil penelitian ini sejalan dengan hasil penelitian yang dilakukan oleh (Purba \& Yadnya, 2015) dan (Yanti \& Budiasih, 2016) yang menyatakan bahwa leverage berpengaruh positif terhadap pengungkapan CSR. Hasil penelitian serupa juga dilakukan oleh (Felicia \& Rasmini, 2015) yang menyatakan bahwa leverage berpengaruh positif terhadap pengungkapan CSR. Leverage yang diproksikan melalui Debt to Equity Ratio (DER) merupakan rasio perbandingan antara total hutang dengan ekuitas yang dimiliki perusahaan, dengan kata lain rasio ini digunakan untuk mengetahui proporsi hutang terhadap modal. Rasio DER berfungsi untuk mengetahui berapa bagian dari setiap modal yang dijadikan sebagai jaminan utang, sehingga akan memberikan petunjuk umum tentang kelayakan kredit dan risiko keuangan debitur (Hery, 2015). (Marzully \& Denies, 2012) menjelaskan bahwa perusahaan dengan leverage yang tinggi membuat perusahaan perlu untuk melakukan pengungkapan tanggung jawab sosial perusahaan secara luas. Hal ini dikarenakan perusahaan dengan tingkat leverage yang tinggi akan berusaha untuk mengurangi sorotan dari debitur sehingga perusahaan dituntut untuk aktif melakukan pengungkapan tanggung jawab sosialnya (Worotikan, 2015). Berdasarkan Teori Stakeholder, perusahaan yang memiliki tingkat leverage yang tinggi akan mengungkapkan lebih banyak informasi kepada para stakeholder untuk menghilangkan keraguan dan menimbulkan kepercayaan akan kemampuan perusahaan karena keberadaan suatu perusahaan sangat dipengaruhi oleh 
dukungan yang diberikan oleh stakeholder perusahaan tersebut. Semakin tinggi rasio Debt to Equity Ratio suatu perusahaan, semakin besar pengungkapan corporate social responsibility yang harus dilakukan oleh perusahaan tersebut.

Berdasarkan hasil penelitian menunjukkan bahwa ukuran perusahaan memperkuat pengaruh profitabilitas pada pengungkapan CSR sehingga hipotesis ketiga dalam penelitian ini diterima. Hasil penelitian memberikan makna bahwa perusahaan yang mempunyai ukuran yang besar tergolong mampu membuat tingkat pencapaian profitabilitas perusahaan itu naik sehingga akan mendapat respon yang positif dari para pelaku pasar seperti investor dan kreditur, di mana yang nantinya akan dapat meningkatkan informasi CSR perusahaan. Hasil penelitian ini sejalan dengan hasil penelitian yang dilakukan oleh (Yuliawati \& Sukirman, 2015) yang menyatakan bahwa ukuran perusahaan memperkuat pengaruh profitabilitas pada pengungkapan CSR perusahaan. Hasil penelitian serupa juga dilakukan oleh (Dermawan, 2015) yang menyatakan bahwa ukuran perusahaan memperkuat pengaruh profitabilitas pada pengungkapan CSR. Mengacu pada teori kontingensi, maka ditemukan hasil penelitian yang dapat menjelaskan pengaruh ukuran perusahaan memoderasi (memperkuat) pengaruh profitabilitas pada pengungkapan CSR. Perusahaan berukuran besar dianggap mampu untuk meningkatkan kualitas labanya melalui peningkatan kinerja manajemen sehingga investor cenderung lebih percaya pada perusahaan besar. Ukuran perusahaan yang dilihat berdasarkan jumlah aset biasanya mengalami fluktuasi dari tahun ke tahun. Ukuran perusahaan memperkuat pengaruh profitabilitas pada pengungkapan CSR karena ketika perusahaan dengan tingkat laba yang tinggi, pihak manajemen perusahaan menganggap perlu adanya laporan mengenai hal-hal yang dapat memberikan informasi keberhasilan keuangan perusahaan. Ukuran perusahaan baik perusahaan besar maupun perusahaan kecil pasti menginginkan dukungan dari para stakeholder-nya untuk menjaga kelangsungan perusahaannya.

Berdasarkan hasil penelitian menunjukkan bahwa ukuran perusahaan tidak mampu memperkuat pengaruh leverage pada pengungkapan CSR sehingga hipotesis keempat dalam penelitian ini ditolak. Hasil penelitian memberikan makna bahwa ukuran perusahaan yang besar atau kecil belum bisa menjamin pengungkapan CSR pada suatu perusahaan, maka ukuran perusahaan tidak mampu mempengaruhi leverage pada pengungkapan CSR secara luas sebelum hutang atau kewajibannya terpenuhi untuk menekan biaya yang akan dikeluarkan dengan adanya pengungkapan CSR tersebut (Setiadewi \& Purbawangsa, 2015). Hasil penelitian ini sejalan dengan hasil penelitian yang dilakukan oleh (Setiadewi \& Purbawangsa, 2015) dan (Pohan et al., 2019) yang menyatakan bahwa ukuran perusahaan tidak mampu memperkuat pengaruh leverage pada pengungkapan CSR. Hasil penelitian tersebut dapat menjelaskan pengaruh ukuran perusahaan tidak mampu mempengaruhi (memperkuat) leverage pada pengungkapan CSR. Dikaitkan dengan teori kontingensi bahwa, ketidakkonsistenan tersebut menghasilkan hasil hipotesis ditolak. Tingkat leverage memberikan pengaruh negatif terhadap pengungkapan corporate social responsibility. Manajemen perusahaan dengan tingkat leverage yang tinggi akan cenderung mengurangi pengungkapan corporate social responsibility supaya tidak menjadi sorotan dari pihak debtholders. 


\section{SIMPULAN}

Simpulan yang dapat diberikan berdasarkan hasil penelitian yang dilakukan yaitu Profitabilitas berpengaruh positif pada pengungkapan CSR di perusahaan pertambangan yang terdaftar di Bursa Efek Indonesia tahun 2017-2019. Artinya bahwa, perusahaan dengan tingkat profitabilitas yang tinggi mencerminkan prestasi kinerja yang baik dan sumber daya yang dimiliki perusahaan semakin besar sehingga berdampak pada meningkatnya harapan stakeholder akan kewajiban perusahaan untuk mengungkapkan informasi terkait kegiatan corporate social responsibility. Leverage berpengaruh positif pada pengungkapan CSR di perusahaan pertambangan yang terdaftar di Bursa Efek Indonesia tahun 20172019. Makna dari hal tersebut adalah semakin tinggi leverage perusahaan yang diproksikan melalui Debt to Equity Ratio (DER), maka rasio leverage yang tinggi akan mengungkapan lebih banyak informasi, karena tanggung jawab perusahaan terhadap para stakeholdernya seperti kreditur dan investor akan lebih besar untuk meningkatkan kepercayaan dan mempermudah dalam permodalannya. Ukuran perusahaan memperkuat pengaruh profitabilitas pada pengungkapan CSR di perusahaan pertambangan yang terdaftar di Bursa Efek Indonesia tahun 20172019. Artinya, semakin tinggi laba yang dihasilkan oleh perusahaan dan dipengaruhi oleh ukuran perusahaan yang semakin besar akan berdampak pada perusahaan tersebut untuk mengungkapkan kegiatan CSRnya. Ukuran perusahaan tidak mampu memperkuat pengaruh leverage pada pengungkapan CSR di perusahaan pertambangan yang terdaftar di Bursa Efek Indonesia tahun 2017-2019. Hal ini dikarenakan ukuran perusahaan yang besar atau kecil belum bisa menjamin pengungkapan CSR yang luas, karena perusahaaan besar atau kecil belum berani melakukan pengungkapan CSR secara luas sebelum hutang atau kewajibannya terpenuhi untuk menekan biaya yang akan dikeluarkan dengan adanya pengungkapan CSR tersebut.

Berdasarkan simpulan, saran-saran yang dapat diberikan Bagi Perusahaan Pertambangan Perusahaan pertambangan disarankan untuk memperhatikan profitabilitas dan leverage yang dapat memengaruhi pengungkapan tanggung jawab sosial perusahaan. Agar citra perusahaan baik dimata para stakeholder dan para pemangku kepentingan, disarankan bagi perusahaan untuk memperhatikan tingkat profitabilitas dan leverage yang dapat memengaruhi besarnya pengungkapan corporate social responsibility. Bagi Peneliti Selanjutnya. Peneliti selanjutnya disarankan untuk melakukan penelitian pada jenis perusahaan berbeda, sehingga hasil penelitian dapat lebih digeneralisasikan. Hal ini dikarenakan hasil penelitian mungkin saja berbeda jika diterapkan pada jenis perusahaan yang berbeda. Mengingat nilai koefisien determinasi dalam penelitian ini adalah sebesar 0,227 atau sebesar 22,7 persen, sehingga sebesar 77,3 persen dipengaruhi oleh variabel lain. Oleh karena itu, peneliti selanjutnya disarankan untuk menambahkan variabel lain khususnya faktor-faktor yang dapat memengaruhi pengungkapan corporate social responsibility, seperti Return on Equity (ROE), Debt to Assets Ratio (DAR) dan sebagainya.

\section{REFERENSI}

Andriana, I. K. G. S., \& Wahyu Purna Anggara, I. W. G. (2019). Pengaruh Ukuran 
Perusahaan, Profitabilitas, Leverage Dan Kepemilikan Saham Publik Pada Pengungkapan Corporate Social Responsibility. E-Jurnal Akuntansi, 29(1), 111. https:/ / doi.org/10.24843/eja.2019.v29.i01.p08

Bhuyan, M., \& Perera, N. (2017). The effects of corporate social disclosure on firm performance : empirical evidence from Bangladesh. Accounting and Finance Association of Australia and New Zealand Conference, 1-36. http:/ / ro.uow.edu.au/ buspapers/1218

Cowen, S. S., Ferreri, L. B., \& Parker, L. D. (1987). The impact of corporate characteristics on social responsibility disclosure: A typology and frequencybased analysis. Accounting, Organizations and Society, 12(2), 111-122. https:/ / doi.org/10.1016/0361-3682(87)90001-8

Dermawan, D. (2015). Faktor-Faktor Yang Mempengaruhi Pengungkapan Corporate Social Responsibility. Accounting Analysis Journal, 4(4). https:/ / doi.org/10.15294/aaj.v4i4.9119

Dewi, M., \& Suaryana, I. (2015). Pengaruh Profitabilitas Dan Kepemilikan Asing Pada Pengungkapan Corporate Social Responsibility. E-Jurnal Akuntansi, 13(1), 84-98.

Gunawan, J., Djajadikerta, H., \& Smith, M. (2009). An examination of corporate social disclosure in the annual reports of Indonesia listed companies. Asia Pacific Centre for Environmental Accountability Journal, 15(1), 13-36.

Komang, N., Trisna, A., Mediatrix, M., \& Sari, R. (2019). E-Jurnal Akuntansi Universitas Udayana Pengaruh Ukuran Perusahaan, Leverage, dan Profitabilitas Pada CSR Disclosure Fakultas Ekonomi dan Bisnis Universitas Udayana (Unud), Bali, Indonesia PENDAHULUAN Modernisasi suatu wilayah sering kali didukung ole. $27,1956-1982$.

McWilliams, A., \& Siegel, D. (2001). Corporate social responsibility: A theory of the firm perspective. Academy of Management Review, 26(1), 117-127. https:/ / doi.org/10.5465/AMR.2001.4011987

Platonova, E., Asutay, M., Dixon, R., \& Mohammad, S. (2018). The Impact of Corporate Social Responsibility Disclosure on Financial Performance: Evidence from the GCC Islamic Banking Sector. Journal of Business Ethics, 151(2), 451-471. https:// doi.org/10.1007/s10551-016-3229-0

Pradnyani, I., \& Sisdyani, E. (2015). Pengaruh Ukuran Perusahaan, Profitabilitas, Leverage, Dan Ukuran Dewan Komisaris Pada Pengungkapan Tanggung Jawab Sosial Perusahaan. E-Jurnal Akuntansi, 11(2), 384-397.

Purba, I., \& Yadnya, I. (2015). Pengaruh Ukuran Perusahaan Dan Leverage Terhadap Profitabilitas Dan Pengungkapan Corporate Social Responsibility. E-Jurnal Manajemen Universitas Udayana, 4(8), 243261.

Rengganis, M. Y. dwi, \& Dwija Putri, I. G. A. . A. (2018). Pengaruh Corporate Governance dan Pengungkapan Corporate Social Responsibility Terhadap Agresivitas Pajak. E-Jurnal Akuntansi, 24, 871. https:/ / doi.org/10.24843/eja.2018.v24.i02.p03

Riswari, D. A., \& Cahyonowati, N. (2012). Pengaruh Corporate Social Responsibility Tehadap Nilai Perusahaan Dengan Corporate Governance Sebagai Variabel Moderating : Studi Pada Perusahaan Publik Non Finansial Yang Tercatat Di Bursa Efek Indonesia. Diponegoro Journal of Accounting, 1(1), $1-12$. 
Setiadewi, K. A. Y., \& Purbawangsa, I. B. A. (2015). Pengaruh Ukuran Perusahaan Dan Leverage Fakultas Ekonomi dan Bisnis Universitas Udayana, Bali , Indonesia dengan Herawati ( 2012 ) yang membuktikan profitabilitas secara signifikan. Pengaruh Ukuran Perusahaan Dan Leverage Terhadap Profitabilitas Dan Nilai Perusahaan, 596-609.

Wiyarna, I. N. A., \& Sudana, I. P. (2019). Determinan Finansial dan Nonfinansial Corporate Social Responsibility Disclosure. E-Jurnal Akuntansi, 29(1), 292. https:/ / doi.org/10.24843/eja.2019.v29.i01.p19

Wulandari, A. A. A. I., \& Sudana, I. P. (2018). Pengaruh Profitabilitas, Kepemilikan Asing, Kepemilikan Manajemen, dan Leverage Pada Intensitas Pengungkapan Corporate Social Responsibility. E-Jurnal Akuntansi, 22, 1445. https:/ / doi.org/10.24843/EJA.2018.v22.i02.p23

Yanti, N. K. A. G., \& Budiasih, I. G. A. N. (2016). Pengaruh Profitabilitas, Leverage Dan Ukuran Perusahaan Pada Pengungkapan Corporate Social Responsibility. E-Jurnal Akuntansi Universitas Udayana, 17(3), 1752-1779.

Yuliawati, R., \& Sukirman. (2015). Accounting Analysis Journal Faktor-Faktor Yang Mempengaruhi Pengungkapan Corporate Social Responsibility. Aaj, 4(4), 1-9. http://journal.unnes.ac.id/sju/index.php/aaj 